\title{
Biodegradation evaluation of bacterial cellulose, vegetable cellulose and poly (3-hydroxybutyrate) in soil
}

\author{
Suellen Brasil Schröpfer ${ }^{1}$, Marcia Karpinski Bottene ${ }^{1}$, Liane Bianchin', Luiz Carlos Robinson', \\ Viviane de Lima ${ }^{1}$, Vanusca Dalosto Jahno ${ }^{1}$, Hernane da Silva Barud ${ }^{2,3}$ and Sidney José Lima Ribeiro ${ }^{4}$ \\ 'Instituto de Ciências Exatas e Tecnológicas, Universidade FEEVALE, Novo Hamburgo, RS, Brazil \\ ${ }^{2}$ Instituto de Química, Universidade Estadual Paulista Júlio de Mesquita Filho - UNESP, \\ Araraquara, SP, Brazil \\ ${ }^{3}$ Grupo de Pesquisa em Química Medicinal e Medicina Regenerativa - QUIMMERA, Laboratório de \\ Química Medicinal e Medicina Regenerativa, Centro Universitário de Araraquara - UNIARA, \\ Araraquara, SP, Brazil \\ ${ }^{4}$ Universidade Estadual Paulista Júlio de Mesquita Filho - UNESP, Araraquara, SP, Brazil \\ *e-mail: vanusca@feevale.br
}

\begin{abstract}
In recent years, the inappropriate disposal of polymeric materials has increased due to industrial development and increase of population consumption. This problem may be minimized by using biodegradable polymers, such as bacterial cellulose and poly(hydroxybutyrate), from renewable resources. This work was aimed at monitoring and evaluating degradation of bacterial cellulose, vegetable cellulose and poly(3-hydroxybutyrate) using Thermogravimetric Analysis and Scanning Electron Microscopy. Controlled mass polymer samples were buried in pots containing soil. Samples were removed in 30 day intervals up to 180 days. The results show that the mass of the polymer increased in the first month when in contact with the soil but then it was degraded as evidenced by mass loss and changes on the sample surface.
\end{abstract}

Keywords: biodegradation, Poly(3-hydroxybutyrate), bacterial cellulose, vegetable cellulose, environmental impact.

\section{Introduction}

The solid waste management is part of the current problem of large urban centers. In Brazil, the solid waste generation has grown $1.3 \%$ from 2011 to 2012 , which is higher than the rate of population growth in the same period $(0.9 \%)$. The amount of solid waste destined inadequately raised in the previous year, totaling 23.7 million tons (42\%) that went to dumps or controlled landfills. Of the total solid waste generated in Brazil in 2012, 13.5\% were plastic materials ${ }^{[1]}$. Although recycling is environmentally appropriate solution, only a small portion of the plastics has recycling potential. Thus, it is necessary a large number of landfills for proper disposal of these materials. Non-biodegradable plastics are an important portion of the solid waste disposed improperly and are responsible for severe environmental problems due to the long time for its decomposition ${ }^{[2,3]}$. In this context, there has been growing interest in the research and development of new biodegradable materials to new applications with minor cost and aiming to decrease environmental impact.

Among these materials, considered biodegradable, are bacterial cellulose (BC) and poly (3-hydroxybutyrate) (PHB) that were constituted by renewable sources ${ }^{[3-8]}$.

For these materials been susceptible to biodegradation it is important that they contains specific chemical groups in its molecular chain to be able to break polymer chain and start the water diffusion, promoting hydrolysis and accessing the enzymatic system which are necessary conditions for biodegradation occurrence ${ }^{[5]}$.
In general context, all polymers are biodegradable, but in different time scales. Biodegradable polymers are considered those who quickly degrade in a few months to two years ${ }^{[9]}$.

Poly alkanoates (PHAs), constitute a class of biodegradable and biocompatible polymers that are produced from renewable resources such as sugars and fatty acids and exhibit thermoplastic properties ${ }^{[10]}$.

Among the most studied PHAs is the poly (3-hydroxybutyrate) (PHB) homopolymer (Figure 1) that presents thermoplastic properties similar to isotactic polypropylene due to its crystallinity and melting point. PHB films have been widely used in special packing production and for biomaterials preparation $^{[10]}$. In this context many studies are now in course in this area ${ }^{[4,11,12]}$.

The other biodegradable polymer is the bacterial cellulose, which has gained attention of many researchers in the last years. Acetobacter $x y$ linum (Gluconacetobacter $x y$ linus) was first described by Brown in 1886. Acetobacter microorganisms are easily found in fruits, vegetables, vinegar, fruit juices and alcoholic drinks ${ }^{[13]}$. Regarding chemical structure, BC is similar to plant cellulose, however, it is obtained like highly hydrated hydrogel ( $99 \%$ water). BC is chemically pure, free of lignin, hemicellulose, and pectin. It shows a nanometric cellulose chains organized in a three-dimensional structural arrangement, which generates a highly crystalline system (60-80\%) with excellent mechanical strength. The nanosized network wires promotes high surface area, 


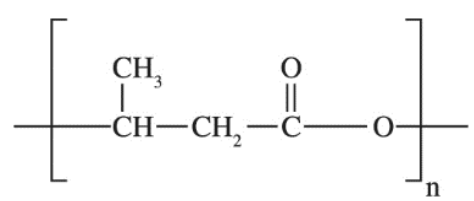

Figure 1. Poly (3-hydroxybutyrate) chemical structure.

surprising absorption capacity and water retention, good elasticity as well as being easily molded ${ }^{[14]}$.

Due to its properties BC can be used in nature, like nanocrystals form or associated with other natural or synthetic polymers to obtain biodegradable materials ${ }^{[15,16]}$.

The vegetable cellulose is the most abundant natural polymer of glucose, being degradable by various bacteria and fungi present in the soil. For its biodegradation has been widely studied, using her as a comparative reference for biodegradation of other materials ${ }^{[17]}$.

The biodegradable materials are those that undergo a significant enough change in their mechanics, physical properties and their chemical structure under specific environmental conditions. These changes result in losses that are measurable by standard test methods.

Polymer degradation is an irreversible process that changes material structure and it is caused by abiotic factors as heat, humidity, water, light, mechanical strength and oxygen $^{[18]}$. When polymer are considered biodegradable and compostable materials they should be accorded with available standards as ASTM D 6400, EN 13432 and NBR 15448 ${ }^{[19]}$

In literature, there are many studies on materials biodegradability, particularly about blends or composites obtained from natural fibers or natural polymers incorporation in non-biodegradable matrix, in order to increase biodegradable degree of these materials or promoting their degradation into smaller time. In this sense there are studies in the literature on the thermo-mechanical behavior of blends and/or different polymer matrix composites with $\mathrm{PHB}$, cellulose or wood and its derivatives incorpored ${ }^{[20-23]}$. However, there are few studies on the behavior of these fillers and natural polymers individually and after soil degradation tests, which makes hard the overall understanding of this type of material. In this context, this work aims the evaluation of soil biodegradation process for bacterial cellulose, vegetable cellulose and poly hydroxybutirate (PHB) using thermogravimetric analysis (TGA) and scanning electron microscopy (SEM).

\section{Materials and Methods}

Never dried bacterial cellulose membranes ( $3 \mathrm{~mm}$ thick containing up to $99 \%$ water were obtained from cultures of isolated wild strain of G. xylinus. Cultivation was conducted for $72 \mathrm{~h}$ at $28{ }^{\circ} \mathrm{C}$ in trays of $30 \times 50 \mathrm{~cm}^{2}$, containing the sterile media composed of glucose $\left(50 \mathrm{~g} \mathrm{~L}^{-1}\right)$, yeast extracts $\left(4 \mathrm{~g} \mathrm{~L}^{-1}\right)$, anhydrous disodium phosphate $\left(2 \mathrm{~g} \mathrm{~L}^{-1}\right)$, heptahydrated magnesium, sulfate $\left(0.8 \mathrm{~g} \mathrm{~L}^{-1}\right)$, and ethanol $\left(20 \mathrm{~g} \mathrm{~L}^{-1}\right)$. BC membranes were several times washed in water, then in 1 mass $\%$ aqueous $\mathrm{NaOH}$ at $70{ }^{\circ} \mathrm{C}$ (in order to remove bacteria) and again in water (until neutral $\mathrm{pH}$ ).
$\mathrm{BC}$ membranes were dried at room temperature. Dried BC membrane shows 20 microns thickness.

PHB samples with molecular weight between $300-500 \mathrm{kDa}$ were supplied by PHB Industrial SA(Usina da Pedra - Serrana - SP/Brazil). Dried PHB films were performed by casting from PHB beads $(2 \% \mathrm{w} / \mathrm{v})$ dissolution in chloroform and subsequently evaporation at room temperature in Petri plates.

Vegetable cellulose (short-fiber bleached eucalyptus cellulose) here designed by standard cellulose, was donated by Celulose Riograndense Brasil.

Samples of polymers were weighed and buried in pots containing Paleudult soil, $\mathrm{pH}$ 6.17, being carried out in triplicate. Samples were removed, washed and dried in intervals up 30 to 180 days. Initial and final samples were available by weight change, thermogravimetric analysis (TGA) and Scanning Electron Microscopy (SEM).

Thermogravimetric analyses were performed in an equipment TGA-50, Shimadzu, with heating ramp of $10^{\circ} \mathrm{C} / \mathrm{min}$ to $1000^{\circ} \mathrm{C}$ under inert nitrogen atmosphere. SEM analyses were realized in a JEOL microscopy, JSM-6510LV model, with secondary electron image.

\section{Results and Discussion}

TG curves for the PHB and bacterial cellulose, are shown in Figure 2. PHB film shows only one thermal degradation step while standard cellulose has two degradation steps.

Was an increase in thermal stability for all the samples in 30 and 60 days of degradation in soil.

Standard cellulose thermograms, Figure 2a, demonstrated an initial weight loss of around 5\% up to $150{ }^{\circ} \mathrm{C}$ corresponding to vaporization of bound or free water and, main decomposition step in the range of 334 to $370{ }^{\circ} \mathrm{C}$ for all samples (30, 60 and 90 days), Figure $2 \mathrm{~b}$, as described in literature ${ }^{[24]}$. The behavior of cellulose thermal degradation has been extensively investigated ${ }^{[25-28]}$ and has been explained for many mechanisms that are not completely known because the complex nature of the reaction. In this sense some pseudo-mechanistic models have been used to explain this process. Generally, these models are based on the fact that, when cellulose is heated in a non-reactive environment, it decomposes to various pyrolysis products. These pyrolysis products can be conveniently grouped into three classes depending on their volatility: tars (mainly anhydro-compounds), char (non-volatile residue, with high carbon content) and gases (low molecular weight products as $\mathrm{CO}, \mathrm{CO}_{2}$, and also water) ${ }^{[25]}$. Cellulose thermal degradation can be described by a mechanism that involves two competitive reactions. The first step that produces carbonaceous residues by cellulose dehydration reactions and a second step that primarily involves reduction in the polymerization degree (depolymerization) and finally the decomposition ${ }^{[24,26,28]}$.

Initial bacterial cellulose, Figure $3 \mathrm{a}$, the analysis demonstrated a degradation range of 327 to $370{ }^{\circ} \mathrm{C}$ however 30 and 60 days samples showed a degradation temperature between 340 and $370{ }^{\circ} \mathrm{C}$, Figure $3 \mathrm{~b}$.

Analyzing TGA results for standard cellulose and bacterial cellulose $\left(200-400^{\circ} \mathrm{C}\right.$ magnification) there is a 
small change on the initial temperature degradation when compared to the initial sample (0 days) to samples after 30 and 60 days. It is know that natural polymers such as cellulose, are hydrolyzed to monomers or oligomers and these are metabolized in the presence or absence of oxygen, but in the other hand metabolic route and final degradation products depends on the electron acceptors available ${ }^{[29]}$. There are no TGA data in the literature that demonstrate the cellulose behavior after degradation tests. One can

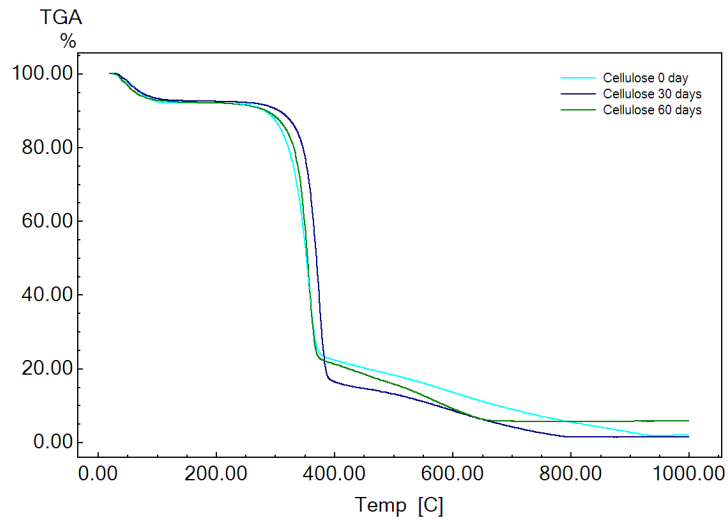

(a) assume that this difference is due to the incorporation of some soil constituent in the sample that caused this observed behavior. Other additional analyzes are needed in order to be assigned to what should be the difference in observed.

The PHB initial sample showed $\mathrm{T}_{\text {on set }}$ of around $276^{\circ} \mathrm{C}$ and $\mathrm{T}_{\text {end set }}$ of $290{ }^{\circ} \mathrm{C}$, Figure 4. According the literature maximum degradation temperature characteristic for PHBs is $290{ }^{\circ} \mathrm{C}^{[30]}$. Thermal degradation of polyesters has been accepted as occurring by intramolecular ester exchange

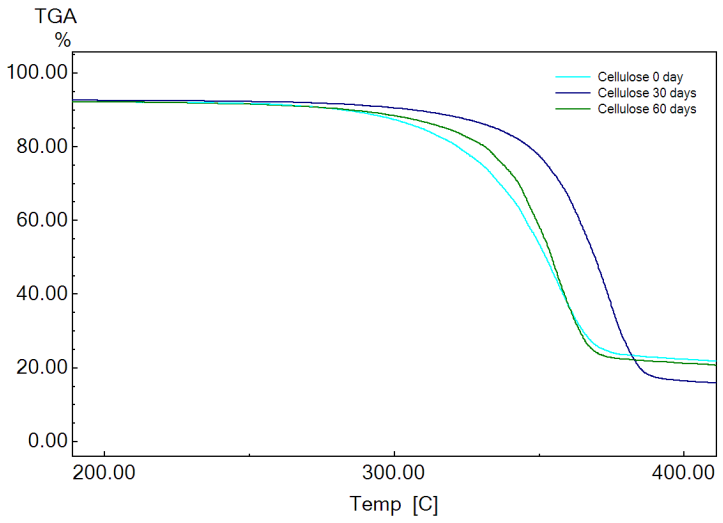

(b)

Figure 2. (a) Standard cellulose thermograms; (b) $200-400{ }^{\circ} \mathrm{C}$ magnification.

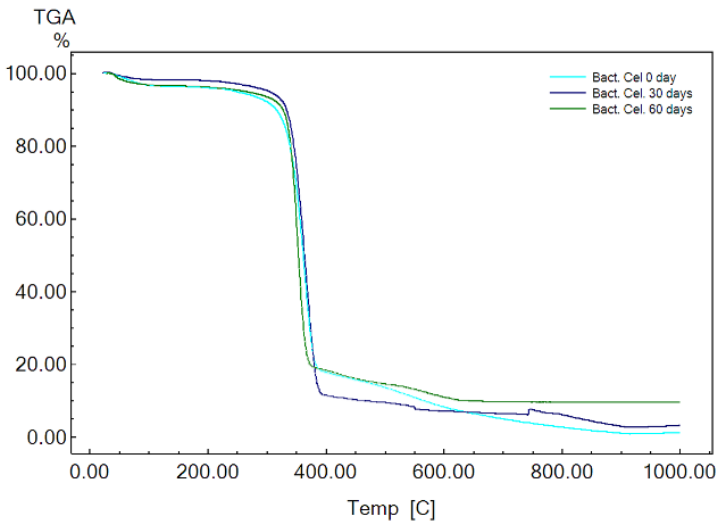

(a)

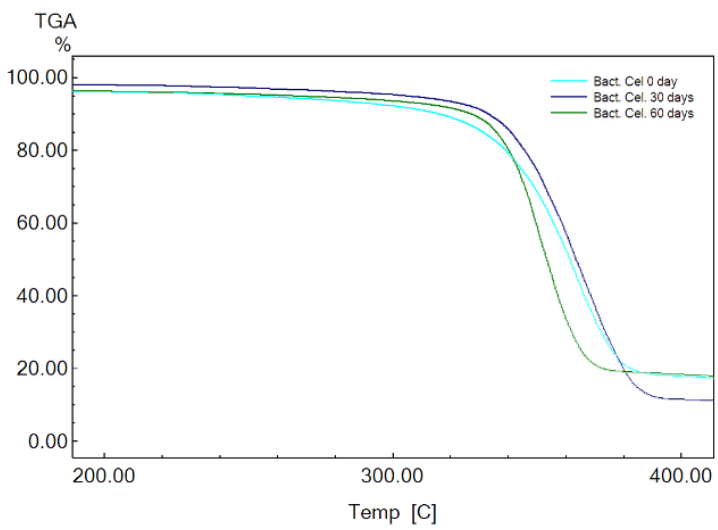

(b)

Figure 3. (a) Bacterial cellulose thermograms; (b) $200-400{ }^{\circ} \mathrm{C}$ magnification.

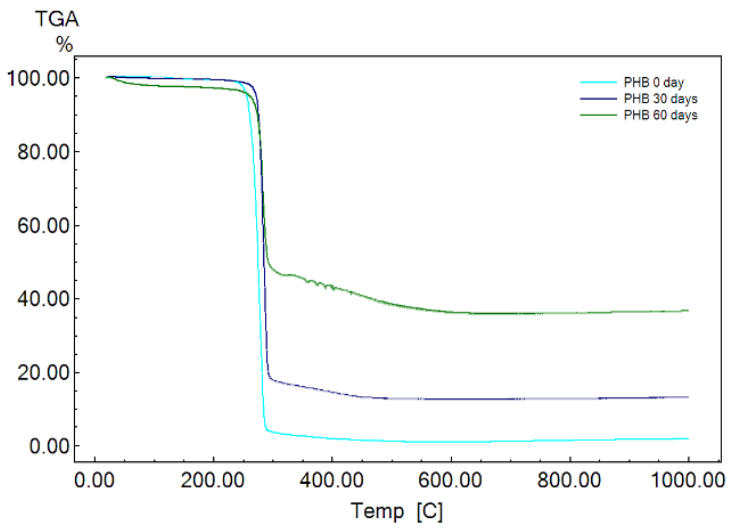

(a)

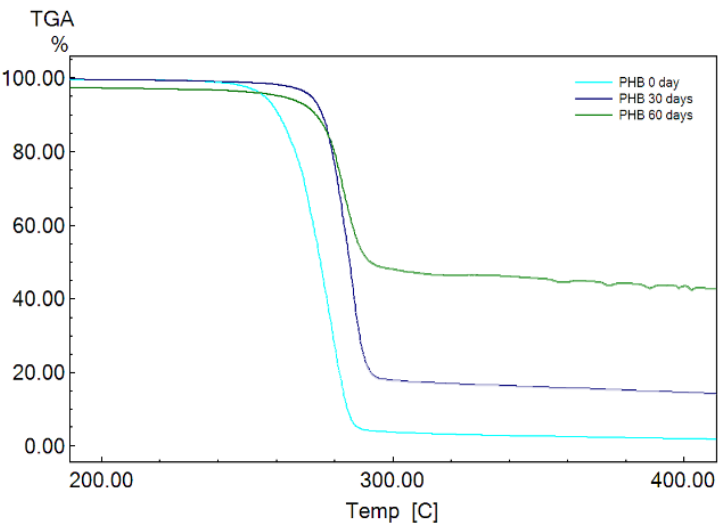

(b)

Figure 4. (a) PHB thermograms; (b) $200-400{ }^{\circ} \mathrm{C}$ magnification. 
(transesterification) and cis-elimination, but most results has been indicated that PHB decomposes according to cis-elimination mechanism ${ }^{[30]}$.

In the same way as for the standard cellulose and bacterial, there is small change in the thermal stability of the material. Moreover, for the sample after 60 days there is a relative increase in the residual mass. This result is unexpected since polyhydroxyalkanoate, as PHB, under aerobic or anaerobic conditions degrade to form carbon dioxide and water or methane and water, respectively ${ }^{[31]}$. This relative mass increase in the 60 -day sample can be

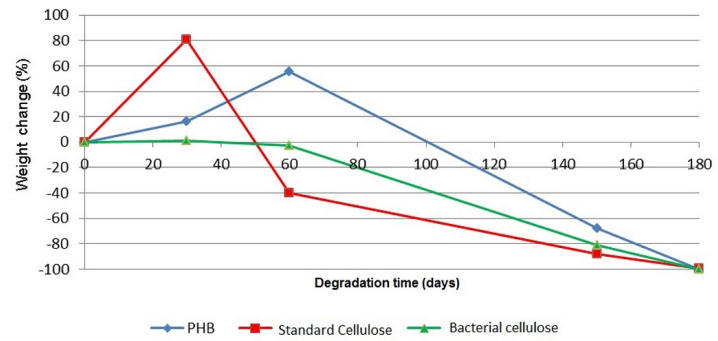

Figure 5. PHB, standard cellulose and bacterial cellulose weight change (\%) after 30, 60, 150 and 180 days of soil degradation. assigned to any constituent present in the soil, but other additional tests are needed to elucidate what occurs during the experiments in soil.

Weight change results have demonstrated a mass increase in the first 30 days for all samples evaluated, where standard cellulose showed the highest percentage (80\%). PHB, standard cellulose and bacterial cellulose mass increase (Figure 5) suggests that samples absorbed water, which facilitates the degradation process, according to the literature $^{[32]}$. Up to 60 days PHB has continued increasing its weight while standard cellulose and bacterial cellulose have lost mass. From 150 days it was verified significant loss mass for PHB (67\%) as for standard cellulose and bacterial cellulose, 88 and $81 \%$, respectively. Up to 180 days all polymer samples were almost completely degraded.

Weight change results are in agreement with those observed by thermogravimetric analysis. From 30 to 60 days there was an increase in the mass and thermal stability, and after 60 days has been the start of the biodegradation process ${ }^{[33]}$.

SEM images for a PHB, standard cellulose and bacterial cellulose, are shown in Figure 6 and Figure 7.

PHB (Figure 6a) and bacterial cellulose (Figure 7a) films before degradation presented smooth surface but with some

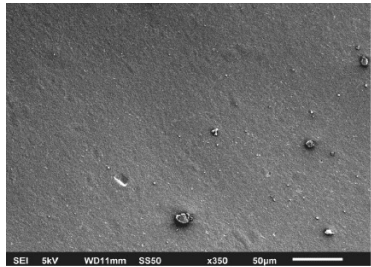

(a)

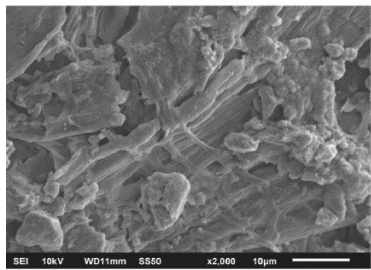

(b1)

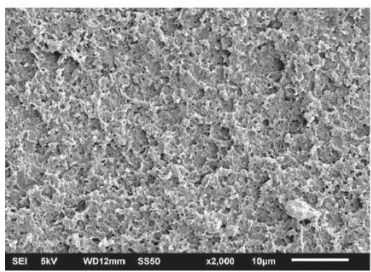

(a3)

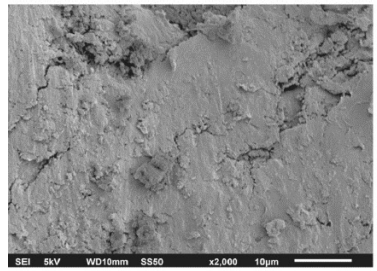

(b4)

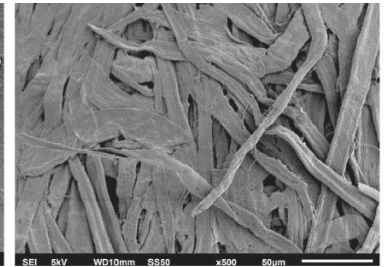

(b)

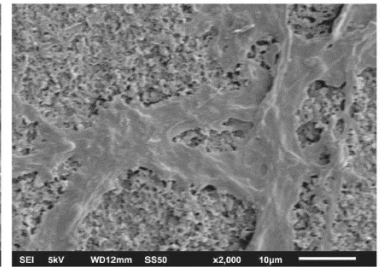

(a2)

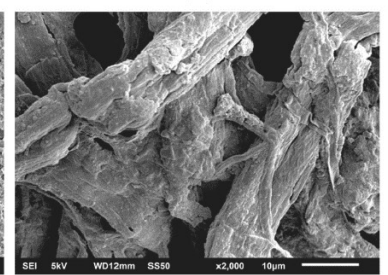

(b3)

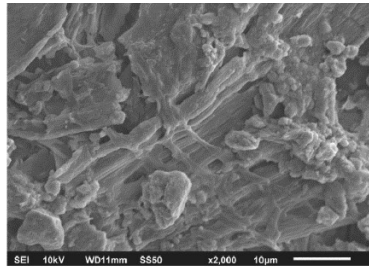

(al)

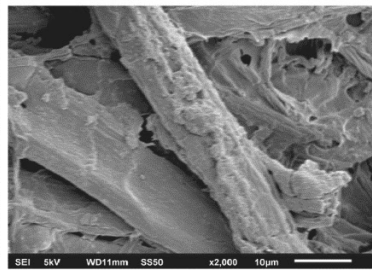

(b2)

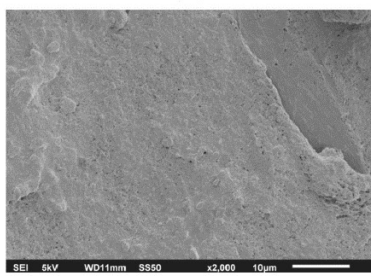

(a4)

Figure 6. PHB and standard cellulose: a) PHB 0 days (350X), b) standard cellulose 0 days (500X); a.1) and b.1) after 30 days of degradation (2000X), a.2) and b.2) after 60 days of degradation (2000X), a.3) and b.3) after 90 days of degradation (2000X), a.4) and b.4) after 150 days of degradation (2000X). 


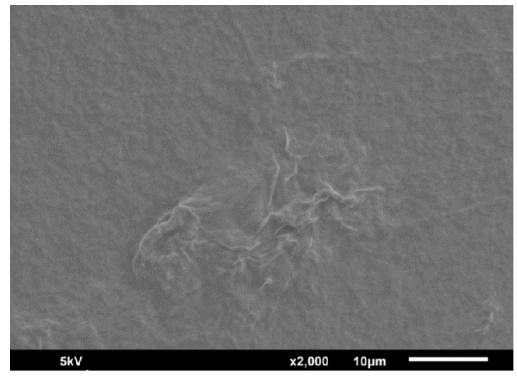

(a)

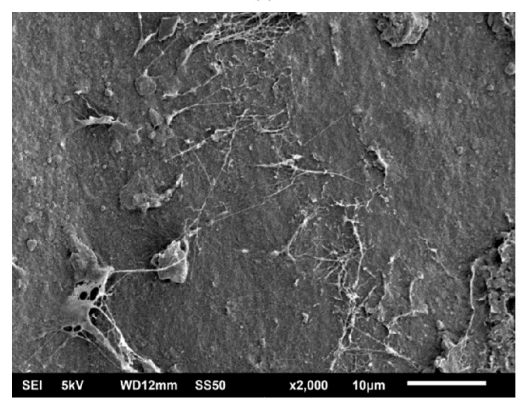

(a2)

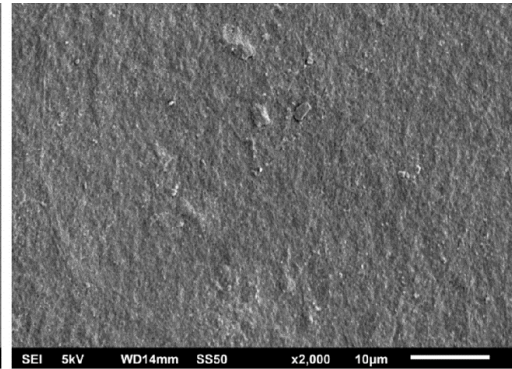

(a1)

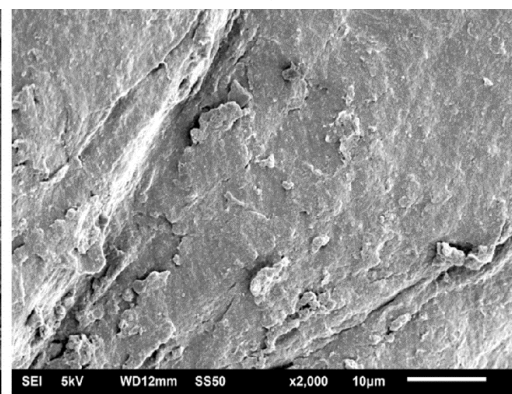

(a3)

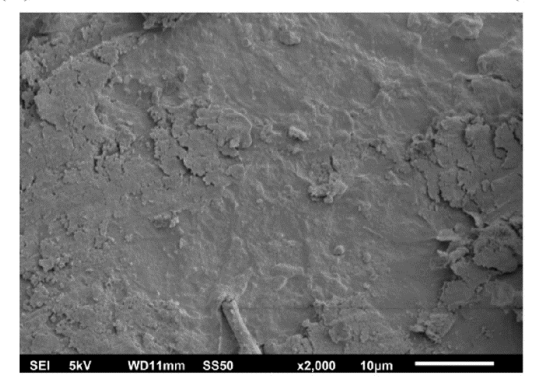

(a4)

Figure 7. Bacterial cellulose micrographs: a) bacterial cellulose 0 days (2000X), a.1) after 30 days of degradation (2000X), a.2) after 60 days of degradation (2000X), a.3) after 90 days of degradation (2000X), a.4) after 150 days of degradation (2000X).

reliefs. Standard cellulose film (Figure 6b) showed fibrous and agglomerated surface. PHB films after 30 days of soil degradation (Figure 6 a.1) exhibited differenced structures, with 60 days of degradation (Figure 6 a.2) the film already has holes and with 90 days (Figure 6 a.3) there has been greater superficial degradation, with the presence of larger holes and spongy surface, likely due to erosion, suggesting microbial adhesion.

Standard cellulose samples (Figure $6 \mathrm{~b}$ ) with degradation time (30, 60, 90 and 150 days) (Figures 6 b.1, 6 b.2, 6 b. 3 and $6 \mathrm{~b} .4)$ fibers were separated and it was evidenced the highest degradation on 90 and 150 days.

Bacterial cellulose after 30 days of degradation (Figure 7 a.1) presented reliefs on its surface. With 60 days (Figure 7 a.2) it was verified fibrils between reliefs with more agglomeration. After 90 and 150 days (Figure 7 a.3 and 7 a.4) it's possible observe surface degradation result of microorganism activity of the soil.

According Campos et al., ${ }^{[34]}$ since microorganisms are able to use surface polymeric components and its metabolism products their release aggressive metabolites such as organic acids and esterases on material surface damaging the area and accelerating the degradation. These morphological alterations caused by microbial colonization are one important factor for the break of polymer chains and for biodegradation. It is known that the enzymatic hydrolysis of biodegradable polyesters mainly occur through surface erosion mechanisms, as cited in the literature ${ }^{[3,35]}$.

\section{Conclusion}

Thermogravimetric and weight change results showed that all samples had presented weight increase in the first month with degradation subsequent. Standard cellulose and bacterial cellulose thermograms evidenced similar thermal behavior, with the main degradation step on 327 to $370^{\circ} \mathrm{C}$, which is consistent with the literature. On the other hand, bacterial cellulose not presented weight loss to $150{ }^{\circ} \mathrm{C}$ corresponding to the vaporization of water. This can be explained by the nature of chemically pure $\mathrm{BC}$, compared to standard cellulose. PHB analyses show a maximum degradation temperature on $290^{\circ} \mathrm{C}$, as reported in literature.

Although weight change results and TGA data showed unexpected results as an increase in the mass and thermal stability, SEM analyzes showed changes in surface in all samples over time. The results here presented are consistent 
with the literature, because the polymers showed degradation. However, it is evident how difficult it is to understand the overall mechanism of degradation of blends or composites, is imperative to know the individual degradation process of these natural polymers.

\section{Acknowledgements}

The authors thank to Celulose Riograndense Brazil, Universidade Feevale, UNESP, UNIARA and CNPq.

\section{References}

1. Associação Brasileira de Empresas de Limpeza Pública e Resíduos Especiais (2012). Panorama dos resíduos sólidos no Brasil 2012. São Paulo: ABRELPE. Retrieved from http:// www.abrelpe.org.br/Panorama/panorama2012.pdf

2. Wu, C.-S. (2009). Renewable resource-based composites of recycled natural fibers and maleated polylactide bioplastic: characterization and biodegradability. Polymer Degradation \& Stability, 94(7), 1076-1084. http://dx.doi.org/10.1016/j. polymdegradstab.2009.04.002.

3. Singh, S., Mohanty, A. K., Sugie, T., Takai, Y., \& Hamada, H. (2008). Renewable resource based biocomposites from natural fiber and polyhydroxybutyrate-co-valerate (PHBV) bioplastic. Composites. Part A, Applied Science and Manufacturing, 39(5), 875-886. http://dx.doi.org/10.1016/j.compositesa.2008.01.004.

4. Falcone, D. M. B., Agnelli, J. A. M., \& Faria, L. I. L. (2007). Panorama setorial e perspectivas na área de polímeros biodegradáveis. Polímeros: Ciência e Tecnologia, 17(1), 5-9. http://dx.doi.org/10.1590/S0104-14282007000100005.

5. Gorna, K., \& Gogolewski, S. (2003). The effect of gamma radiation on molecular stability and mechanical properties of biodegradable polyurethanes for medical applications. Polymer Degradation \& Stability, 79(3), 465-474. http://dx.doi. org/10.1016/S0141-3910(02)00362-2

6. Huda, M. S., Drzal, L. T., Misra, M., Mohanty, A. K., Williams, K., \& Mielewski, D. F. (2005). A study on biocomposites from recycled newspaper fiber and poly(lactic acid). Industrial \& Engineering Chemistry Research, 44(15), 5593-5601. http:// dx.doi.org/10.1021/ie0488849.

7. Bhardwaj, R., Mohanty, A. K., Drzal, L. T., Pourboghrat, F., \& Misra, M. (2006). Renewable resource-based green composites from recycled cellulose fiber and poly (3-hydroxybutyrate-co3-hydroxyvalerate) bioplastic. Biomacromolecules, 7(6), 20442051. http://dx.doi.org/10.1021/bm050897y. PMid:16768432

8. Yu, L., Dean, K., \& Li, L. (2006). Polymer blends and composites from renewable resources. Progress in Polymer Science, 31(6), 576-602. http://dx.doi.org/10.1016/j.progpolymsci.2006.03.002.

9. Sadi, R. K. (2010). Estudo da compatibilização e da degradação de blendas polipropileno/poli (3-hidroxibutirato)(PP/PHB) (Tese de doutorado). Escola Politécnica, Universidade de São Paulo, São Paulo.

10. Coutinho, B. C., Miranda, G. B., Sampaio, G., Souza, L. B. S., Santana, W. J., \& Coutinho, H. D. M. (2004). A importância e as vantagens do polihidroxibutirato (plástico biodegradável) Holos, 20, 76-81. http://dx.doi.org/10.15628/holos.2004.49.

11. Franchetti, S. M. M., \& Marconato, J. C. (2006). Biodegradable polymers - a partial way for decreasing the amount of plastic waste. Quimica Nova, 29(4), 811-816. http://dx.doi.org/10.1590/ S0100-40422006000400031.

12. Calvão, P. S. (2009). Obtenção e caracterização de misturas do polímero biodegradável $P[3 H B]$ e seu copolímero $P[3 H B-c o-$ $3 H V]$ com elastômeros (Tese de doutorado). Escola Politécnica, Universidade de São Paulo, São Paulo.
13. Czaja, W. K., Young, D. J., Kawecki, M., \& Brown, R. M. Jr (2007). The future prospects of microbial cellulose in biomedical applications. Biomacromolecules, 8(1), 1-12. http://dx.doi. org/10.1021/bm060620d. PMid:17206781

14. Klemm, D., Heublein, B., Fink, H. P., \& Bohn, A. (2005). Cellulose: fascinating biopolymer and sustainable raw material. Polymer Science, 44(22), 3358-3393. http://dx.doi.org/10.1002/ anie. 200460587

15. Barud, H. S., Barrios, C., Regiani, T., Marques, R. F. C., Verelst, M., Dexpert-Ghys, J., Messaddeq, Y., \& Ribeiro, S. J. L. (2008). Self-supported silver nanoparticles containing bacterial cellulose membranes. Materials Science and Engineering, 28(4), 515-518. http://dx.doi.org/10.1016/j.msec.2007.05.001.

16. Barud, H. S., Ribeiro, S. J. L., Carone, C. L. P., Ligabue, R., Einloft, S., Queiroz, P. V. S., Borges, A. P. B., \& Jahno, V. D. J. (2013). Optically transparent membrane based on bacterial cellulose/polycaprolactone. Polímeros, 23(1), 135-142. http:// dx.doi.org/10.1590/S0104-14282013005000018.

17. Sannino,A., Demitri, C., \& Madaghiele, M. (2009). Biodegradable Cellulose-based Hydrogels: Design and Applications. Materials, 2(2), 353-373. http://dx.doi.org/10.3390/ma2020353.

18. Mei, L. H. I., \& Mariani, P. D. S. C. (2005). Visão geral sobre polímeros ou plásticos ambientalmente degradáveis. Campinas: Unicamp.

19. Harada, J., \& Manosso, L. (2008). Polimeros de fontes renováveis, biodegradáveis e compostáveis. In Anais do Seminário de Reciclagem e Valorização dos Resíduos Sólidos. Porto Alegre.

20. Okelo, A. P. (2012). Mechanical, thermal, diffusion and degradation properties of high density polyethylene 'and' cellulose blends (Dissertação de mestrado). Kenyatta University, Nairobi.

21. Kalka, S., Huber, T., Steinberg, J., Baronian, K., Müssig, J., \& Staiger, M. P. (2014). Biodegradability of all-cellulose composite laminates. Composites. Part A, Applied Science and Manufacturing, 59, 37-44. http://dx.doi.org/10.1016/j. compositesa.2013.12.012.

22. Azzaoui, K., Lamhamdi, A., Mejdoubi, M., Berrabah, M., Hammouti, B., Elidrissi, A., Fouda, M. M. G., \& Al-Deyab, S. S. (2014). Synthesis and characterization of composite based on cellulose acetate and hydroxyapatite application to the absorption of harmful substances. Carbohydrate Polymers, 111, 41-46. http://dx.doi.org/10.1016/j.carbpol.2014.04.058. PMid:25037327

23. Mousavioun, P., George, A. G., \& Doherty, W. O. S. (2012). Environmental degradation of lignin/poly(hydroxybutyrate) blends. Polymer Degradation \& Stability, 97(7), 1114-1122. http://dx.doi.org/10.1016/j.polymdegradstab.2012.04.004.

24. Poletto, M., Pistor, V., Zeni, M., \& Zattera, A. J. (2011). Crystalline properties and decomposition kinetics of cellulose fibers in wood pulp obtained by two pulping processes. Polymer Degradation \& Stability, 96(4), 679-685. http://dx.doi. org/10.1016/j.polymdegradstab.2010.12.007.

25. Conesa, J. A., Caballero, J. A., Marcilla, A. R., \& Font, R. (1995). Analysis of different kinetic models in the dynamic pyrolysis of cellulose. Thermochimica Acta, 254(15), 175-192. http://dx.doi.org/10.1016/0040-6031(94)02102-T.

26. Soares, S., Camino, G., \& Levchik, S. (1995). Comparative study of the thermal decomposition of pure cellulose and pulp paper. Polymer Degradation \& Stability, 49(2), 275-283. http:// dx.doi.org/10.1016/0141-3910(95)87009-1.

27. Capart, R., Khezami, L., \& Burnham, A. K. (2004). Assessment of various kinetic models for the pyrolysis of a microgranular cellulose. Thermochimica Acta, 417(1), 79-89. http://dx.doi. org/10.1016/j.tca.2004.01.029.

28. Quiévy, N., Jacquet, N., Sclavons, M., Deroanne, C., Paquot, M., \& Devaux, J. (2010). Influence of homogenization and 
drying on the thermal stability of microfibrillated cellulose. Polymer Degradation \& Stability, 95(3), 306-314. http://dx.doi. org/10.1016/j.polymdegradstab.2009.11.020.

29. Cunha-Santino, M. B. (2003). Atividade enzimática, cinética e modelagem matemática da decomposição de Utricularia breviscapa da lagoa do Óleo (Estação Ecológica de Jataí, Luiz Antônio-SP) (Tese de doutorado). Universidade Federal de São Carlos, São Carlos.

30. Kopinke, F.-D., Remmler, M., \& Mackenzie, K. (1996). Thermal decomposition of biodegradable polyesters-I: Poly $(\beta$ hydroxybutyric acid). Polymer Degradation \& Stability, 52(1), 25-38. http://dx.doi.org/10.1016/0141-3910(95)00221-9.

31. Boyandin, A. N., Prudnikova, S. V., Karpov, V. A., Ivonin, V. N., Đỗ, N. L., Nguyễn, T. H., Lê, T. M. H., Filichev, N. L., Levin, A. L., Filipenko, M. L., Volova, T. G., \& Gitelson, I. I. (2013). Microbial degradation of polyhydroxyalkanoates in tropical soils. International Biodeterioration \& Biodegradation, 83, 77-84. http://dx.doi.org/10.1016/j.ibiod.2013.04.014.

32. Rosa, D. S., Guedes, C. G. F., \& Bardi, M. A. G. (2007). Evaluation of thermal, mechanical and morphological properties of PCL/CA and PCL/CA/PE-g-GMA blends.
Polymer Testing, 26(2), 209-215. http://dx.doi.org/10.1016/j. polymertesting.2006.10.003.

33. Quental, A. C., Carvalho, F. P., Tada, E. S., \& Felisberti, M. I. (2010). Blends of PHB and its copolymers: miscibility and compatibility. Quimica Nova, 33(2), 438-446. http://dx.doi. org/10.1590/S0100-40422010000200035.

34. Campos, A., Marconato, J. C., \& Martins-Franchetti, S. M. (2011). Biodegradation of blend films PVA/PVC, PVA/PCL in soil and soil with landfill leachate. Brazilian Archives of Biology and Technology, 54(6), 1367-1378. http://dx.doi. org/10.1590/S1516-89132011000600024.

35. Tao, J., Song, C., Cao, M., Hu, D., Liu, L., Liu, N., \& Wang, S. (2009). Thermal properties and degradability of poly(propylene carbonate)/poly( $\beta$-hydroxybutyrate-co- $\beta$-hydroxyvalerate) (PPC/ PHBV) blends. Polymer Degradation \& Stability, 94(4), 575583. http://dx.doi.org/10.1016/j.polymdegradstab.2009.01.017.

Received: Mar: 09, 2014

Revised: Sept. 08, 2014 Accepted: Out. 20, 2014 